\title{
Leadership Mindsets of First-Year Undergraduate Students: An Assessment of a Leadership-Themed Living Learning Community
}

\author{
Allison L. Dunn \\ Ph.D. Student \\ Department of Agricultural Leadership, Education \& Communications \\ Texas A\&M University \\ College Station, TX 77843-2116 \\ aldunn@tamu.edu \\ Summer F. Odom \\ Assistant Professor \\ Department of Agricultural Leadership, Education, \& Communications \\ Texas A\&M University \\ College Station, TX 77843-2116 \\ summerodom@tamu.edu \\ Lori L. Moore \\ Associate Professor \\ Department of Agricultural Leadership, Education \& Communications \\ Texas A\&M University \\ College Station, TX 77843-2116 \\ 1lmoore@tamu.edu \\ Craig Rotter \\ Assistant Director for Academic Support Initiatives \\ Department of Residence Life \\ College Station, TX 77843-1253 \\ craigr@housing.tamu.edu
}

\begin{abstract}
First-year college students in a leadership-themed living-learning community $(N=60)$ at Texas A\&M University were surveyed to examine if participation in the learning community influenced their leadership mindset using hierarchical and systemic thinking preferences. Utilizing a pre-test and post-test methodology, significant differences for hierarchical thinking were not found; however, significant differences for systemic thinking were found. At the end of the program year, students had larger systemic scores than when they started the program, but their hierarchical thinking scores remain fairly steady. Findings indicated that participation in a leadership-themed living-learning community influenced students' leadership mindsets.
\end{abstract}




\section{Introduction}

The leadership development of college students is a growing field of inquiry within both academic and student affairs. Increasingly, college campuses are looking for ways to enhance students' learning environments by encouraging partnerships between academic and student affairs. The academically-themed living-learning community (LLC) is one way academic and student affairs departments are collaborating to provide enhanced learning environments on college campuses, especially at sizable institutions (Dunn \& Dean, 2013). As Ineklas et al. (2006) reported, the goal of the LLC is to, "create a smaller community, within an institution to help foster students' learning and development” (p. 116-117).

The modern LLC is grounded in the work of Meiklejohn and the concept of the Experimental College at the University of Wisconsin in 1927 (Powell, 1981). Meiklejohn's focus was the improvement of the first two years of an undergraduate education. He advocated that, for improvement to occur, students should live together and engage in common courses to enhance their "intelligence" and ability to critically examine the world around them (Dunn \& Dean, 2013; Powell, 1981). The desire and need for continuous improvement of undergraduate education still exists today. Consequently, modern LLCs are developed and designed as a high impact practice aimed at improving the educational environment to subsequently improve educational outcomes of undergraduate students (Rocconi, 2011). By focusing on active rather than passive learning, LLCs are able to create a sense of community within the participants and between the program participants and their faculty members, thus providing a positive environment for improved educational outcomes (Cross, 1998). Furthermore, the modern LLC provides an intentional approach to education through expanded control of the living environment, in that the residence hall becomes an extension of the classroom, and the programmatic aspects of the LLC are designed to provide a sense of community and student support, in addition to academic exploration (Longerbeam, Inkelas, \& Brower, 2007).

While modern LLCs have a philosophical home in Meiklejohn's work, most leadershipthemed LLCs appeared as the academic examination of leadership gained momentum, leadership departments took shape, and leadership gained status as a field of study. Additionally, with the collaborative nature of the LLC, requisite student affairs departments and staff who are skilled in and knowledgeable of leadership theories and constructs needed to be identified before the program could be implemented. Consequently, most leadership-themed LLCs are relatively recent additions to college campuses.

Even though the LLC model is gaining national popularity across college campuses, LLCs have not been systematically researched or assessed (Inkelas et al., 2006). This lack of systematic research is partly due to the individualized nature of these programs, which makes comparative analysis of programs between institutions quite difficult. Additionally, leadershipthemed LLCs are fewer in number nationally than most other LLCs. As a result, both the need for research of and difficulty in examining the programs collectively increases.

Further complicating the situation is the lack of a common definition of leadership and the small body of research focused on undergraduate students' development of leadership mindsets. Following the multiple leadership definitions are the multiple ways of engaging in 
leadership behavior. Over the last sixty years, leadership theories have shifted from being solely leader-centric and positional, to more relational between leaders and followers (Northouse, 2016). The call to evaluate and assess leadership programs is clearly expressed in Priority II of the Association of Leadership Educator's National Leadership Education Research Agenda (Andenoro et al., 2013). Leadership educators must engage in, "programmatic monitoring and evaluation ... a as they attempt to determine if their practice is achieving the desired outcomes" (Andenoro et al., 2013, p. 10).

Started in 2005, the Leadership Living Learning Community (L3C) is a collaborative initiative between the Departments of Residence Life and Agricultural Leadership, Education, \& Communications (ALEC) for first-year students at Texas A\&M University. Any first-year college student, regardless of major or previous leadership experience, is welcome and encouraged to apply to the L3C. Approximately ninety students are selected each spring semester to participate the following fall semester. The L3C is a year-long program consisting of two one-credit hour introductory leadership courses, one each semester, co-taught by faculty within ALEC and Residence Life, and a series of co-curricular leadership-learning experiences facilitated by previous L3C students, the peer mentors. All L3C participants live on the same floor of the same residence hall, and the learning community is supported by two undergraduate Residence Assistants who are also former L3C participants.

The peer mentors are sophomores who have recently completed the L3C and live in the residence hall with the L3C participants. Paired with another peer mentor, each dyad is responsible for a group of between twelve and fifteen L3C students each semester. In addition to the co-curricular experiences they facilitate, the peer mentors also enroll in two upper-division leadership courses within the ALEC Department: Survey of Leadership Theory and a selfdirected independent study course directly related to leadership studies and their work within the L3C.

As research on leadership-themed LLCs is limited, this study provided an opportunity to expand the body of research and to collect data measuring the leadership mindset of first-year college students who are not declared leadership majors nor minors, but have an expressed interest in leadership studies and the development of their personal leadership competency and capacity.

\section{Literature Review and Conceptual Framework}

College graduates who demonstrate leadership skills are in high demand; therefore, colleges and universities are investing resources in leadership development programs to meet this need (Haber, 2012; Shertzer et al., 2005). LLCs are an example of a high impact practice being utilized by universities to achieve their goal of producing the next generation of leaders (Cross, 1998; Rocconi, 2011). While learning communities range in size, scope, and structure, all are used to improve undergraduate education with a focus on collaborative learning (Cross, 1998). The LLC intensifies the potential for collaboration by placing students who are taking the same class(es) in close residential proximity; same section of a floor, the same floor, or the same residence hall, depending on size of the community and the building. Longerbeam et al. (2007) noted that the positive impacts of living on campus can be augmented through intentional co- 
curricular programmatic offerings, like those found within a LLC.

Thus, with the residence hall as an extension of the classroom, students are able to continue class discussions and engage in other skill development activities within the safety and comfort of their living community. According to Cross (1998), "knowledge requires language, and people construct knowledge out of the language available to them in their community" (p. 5). Consequently, if the goal is to expand students' perceptions and perspectives, then LLCs should provide programmatic offerings to engage students in conversations outside the classroom. Inkelas and Weisman (2003) indicated that providing multiple perspectives only in class is not enough to change personal perspective. Additionally, work by Inkelas et al. (2006) detailed how the LLC promotes students' abilities to understand and critically examine differing perspectives from their own. Thereby making the LLC the perfect intersection for curricular and co-curricular learning (Dunn \& Dean, 2013).

Research repeatedly has shown the benefits of learning communities, residential or otherwise. From positive academic gains, like transition to college, persistence and graduation, problem-solving skills, writing ability, and increased time spent on academics, to increased socialization, involvement on campus, and greater connection with their campus, students benefit from being in a learning community (Cross, 1998; Inkelas et al., 2006; Inkelas \& Weisman, 2003; Inman \& Pascarella, 1998; Pike, 1999; Rocconi, 2011). Davis and Murrell (1993) concluded, "for growth to occur, the work that is done in the classroom must find expression in other aspects of a student's life" (p. 286). Yet, the self-selection of students by applying to participate in a LLC, especially when first-year college students are not mandated to live oncampus, makes it difficult to know if the gains observed in LLC participants are due to the LLC experience alone or are a result of the type of students who apply to and choose to participate in a LLC (Inkelas \& Weisman, 2003).

In a leadership-themed LLC, the collaborative learning revolves around leadership concepts, capacity, and competency development with curricular activities augmented by peerled co-curricular activities. As the students are exposed to new concepts, a variety of leadership perspectives, and challenged to engage in their own learning, their leadership capacity and competency increases. Thus, understanding the leadership messages students receive from their living situation may be important when seeking to increase and/or improve students' leadership development opportunities both in and outside the classroom (Shertzer et al., 2005). Furthermore, the co-curricular experiences students engage in within their residencehalls positively contribute to students' overall learning (Inkelas et al., 2006).

But understanding how a student's living situation impacts students' understanding of leadership only illuminates one aspect of the challenge to improve collegiate leadership programs. It is also central to understand how students conceptualize leadership on their own (Haber, 2012) and to understand from where students gain their comprehension of leadership: academic coursework, student organizations, employment, etc. (Ho \& Odom, 2015). Moreover, Keating, Rosch and Burgoon (2014) detailed that students with low leadership self-efficacy upon entering an introductory leadership course show no significant gains in leadership skill after taking the course. However, research has also shown that formal leadership courses do influence a student's leadership mindset, and that the more leadership courses a student completes, the 
more likely students are to shift their leadership mindset from one of rigid, linear rankings with control, power, and authority focused at the top of the organization, or hierarchical thinking, to one of relational processes where organization members collectively influence decisions and flexibility and adaptability are valued, or systemic thinking (Ho \& Odom, 2015; Wielkiewicz, Prom, \& Loos, 2005). Therefore, the need exists to help students understand how they conceptualize leadership and their leadership self-efficacy before time is spent focused on specific leadership skill development, so students are better prepared for and able to articulate the shift in their leadership mindset, thereby recognizing their own leadership development.

As the L3C program is only open to first-year college students and the two leadership courses in the L3C program combined count for two-thirds of the introductory course in the leadership major/minor at Texas A\&M University, L3C participants are at the beginning of their collegiate leadership journey. Hence, the end of the L3C program year is the ideal time to examine their conceptualization of leadership - prior to their progression into additional leadership courses or their collegiate co-curricular leadership experience. A previous study at Texas A\&M University surveyed students within the leadership major and determined that female students were higher in systemic thinking and lower in hierarchical thinking than male students, supporting previous research (Haber, 2012; Wielkiewicz, Fischer, Overland, \& Sinner, 2012). Additionally, it was reported that seniors were both higher in systemic thinking and lower in hierarchical thinking than first-year students (Ho \& Odom, 2015).

By utilizing small groups for the co-curricular experiences, the L3C garners the benefits of both a large seminar, i.e. everyone attends the same lecture, and the benefits of a small instruction setting, i.e. personal attention and interaction with a focus on application of topics discussed in lecture as well as community building. Since one-size-fits-all leadership programs only result in gains for some, individual attention and opportunities for personal application and development are important if all members of the program are to benefit (Keating et al., 2014). Cross (1998) has shown that utilizing small groups within large classes help students develop connections and understanding of more complex concepts. Hence increased numbers of campuses are implementing LLCs as a means for a large campus to feel more intimate, to create more intentional support systems for students, and to provide faculty and students opportunities to purposefully connect outside of the classroom (Dunn \& Dean, 2013).

In regards to students' conceptualization of leadership, Thompson (2013) noted that faculty interactions were the most important contributing institutional resource towards students' belief system concerning leadership. Therefore, having increased opportunities for faculty and student interaction provides increased opportunities to influence students' conceptualization of leadership. Yet the opportunity for faculty and student interaction is not enough. Both formal and informal interactions are needed to create an environment conducive to students' intellectual development towards leadership (Thompson, 2013), so interactions both within and outside the classroom are needed.

One's intellectual development regarding leadership is seen as creating a leadership identity, and is both a linear and cyclical process influenced by a wide array of life experiences. Komives, Owen, Longerbeam, Mainella, and Osteen's Leadership Identity Development (LID) model (2005), is a grounded theory approach detailing the process whereby college students 
develop their leadership identity. As an individual's leadership identity advances, Komives et al. (2005) identified six stages or leadership constructs a person passes through: awareness, exploration/engagement, leadership identified, leadership differentiated, generativity, and integration/synthesis (see Figure 1).

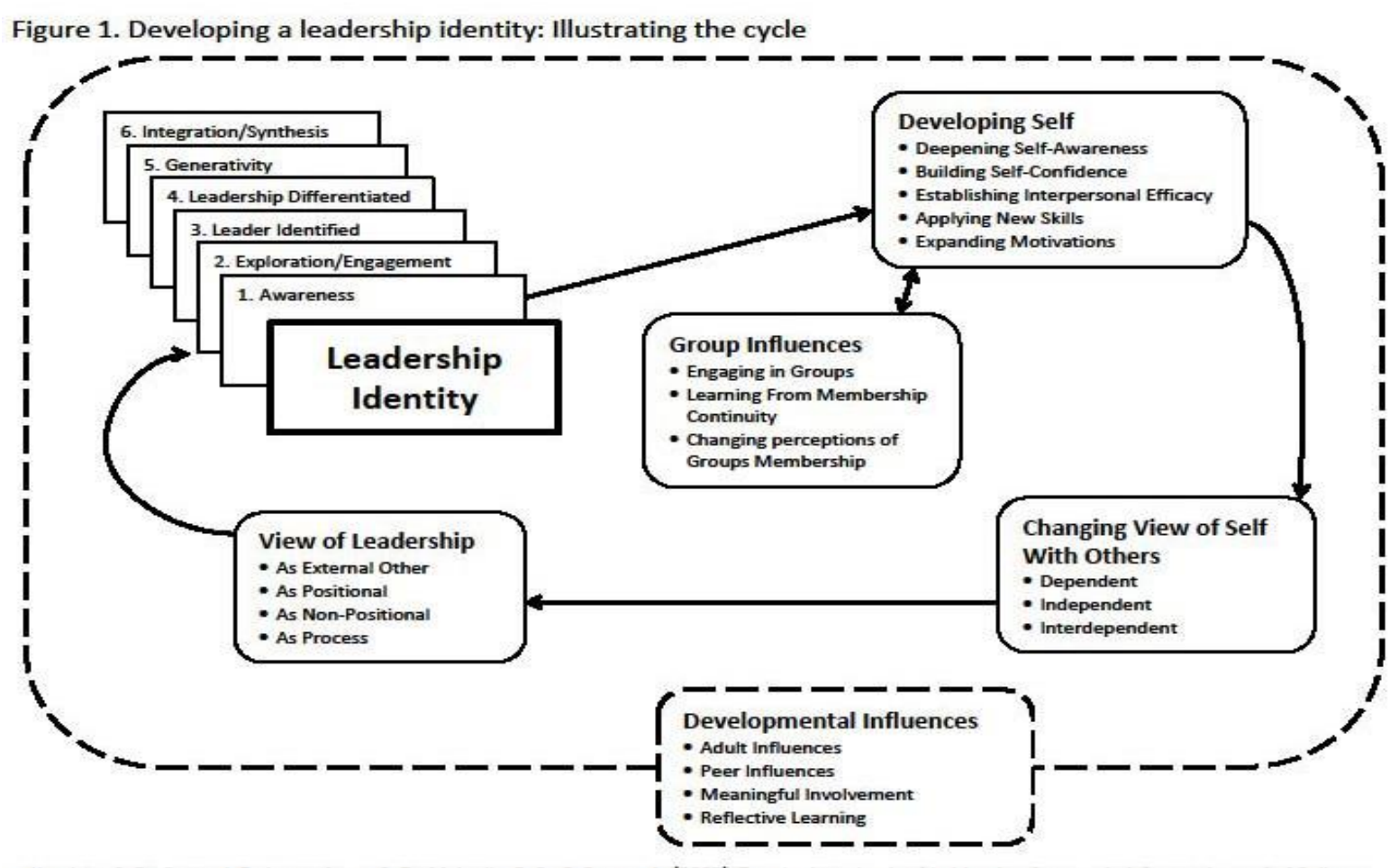

Komives, S. R., Owen, J. E., Longerbeam S. D., Mainella, F. C., \& Osteen, L (2005). Developing a leadership identity: A grounded theory. Jaurnal of College Student Development, 46(6), 593-611. doi: 10.1353/csd.2005.0061

While development through these stages is sequential, it is also cyclical (Komives et al., 2009). As one matures, they progress linearly from stage one to stage two, needing to gain experience with the aspects of a stage before moving on to the next, with the end goal being stage six. However, simultaneously, each individual's life experiences are cyclically influencing the depth of development within each stage. Komives, Longerbeam, Owen, Mainella, \& Osteen (2006) identified five categories by which stage development is influenced: broadening view of leadership, developing self, group influences, developmental influences, and the changing view of self with others. Expanding in complexity and progressing from leadership being independent of the participant, to leadership being an action of those with a position, to leadership being a relational process between interdependent participants, the six stages of the LID model enable researchers to categorize students' development at a given point in time.

While these five categories provide the basis for much research centered on the LID model, this model can also be used to study significant changes in a students' conceptualization of leadership, i.e. the transitions between stages (Komives et al., 2006). The most pronounced shift in the LID model comes at the end of stage three when individuals move from viewing leadership as a position to leadership as a non-positional process (Komives et al., 2009). Up until stage three, leadership is seen as positional, something that the person in charge does, and a hierarchical thinking approach to leadership is maintained. But by stage four, individuals tend to differentiate their view of leadership in that leadership was now both a process as well as the 
actions of the positional leader (Komives et al., 2006). This shift is important as the remaining stages of the LID model deal with the relational and systemic aspects of leadership. Thus, the LID model enables researchers to gather information on how individuals perceive or make meaning of their leadership experiences and the world around them (Komives et al., 2009).

One research application of the LID model is the analysis of college students' leadership mindsets, or their attitudes and beliefs regarding leadership. Multiple studies utilizing the Leadership Attitudes and Beliefs Scale (LABS) have been conducted to determine how students without formal leadership positions view leadership and expect leaders to behave (Ho \& Odom, 2015; Wielkiewicz, 2002; Wielkiewicz, Fisher, Overland, \& Sinner, 2012; Fischer, Wielkiewicz, Stelzner, Overland, \& Meuwissen, 2015). As previously stated, individuals who believe leadership is hierarchical tend to view leadership as the actions of the positional leader of the organization, who is responsible for the success of the organization. However, individuals who believe leadership is systemic view leadership as a collaborative process where all members of the organization contribute to the leadership activities and share responsibility for the success of the organization (Wielkiewicz, 2000). Komives et al. (2005) noted the transition from stage three to stage four indicated the shift between hierarchical and systemic views of leadership. Consequently, understanding if students view leadership as hierarchical or systemic has implications for the development and implementation of collegiate leadership programs (Haber, 2012).

\section{Purpose and Objectives}

This study sought to investigate leadership experiences and leadership mindsets of students participating in a leadership-themed living learning community. Specifically, this study addressed the following objectives:

1. Describe the leadership experiences of L3C students prior to attending college and after the second semester in college.

2. Describe L3C students' leadership mindsets in terms of hierarchical and systemic thinking.

3. Compare students' leadership mindsets from the beginning of the $\mathrm{L} 3 \mathrm{C}$ to the end of the second semester of the L3C.

\section{Methodology}

Population and Sample. This research was conducted at a large, public, research institution in the southern United States. The population was first-year undergraduate students enrolled in a two-semester leadership-themed living-learning community (L3C) at Texas A\&M University during the fall 2013 and spring 2014 semesters. As part of the L3C, students complete a one hour academic course in the fall and spring semesters. Content in the course focuses on the relational and process approach to leadership rather than the hierarchical. There were 65 students participating in the L3C during the fall 2013 semester and 58 students participating in the L3C during the spring 2014 semester. A total of 60 students $(\mathrm{n}=60,92.3 \%)$ completed the pre-test instrument for this study, which was administered in the fall 2013 semester. A total of 55 students $(n=55,94.8 \%)$ completed the post-test instrument, which was 
administered in the spring 2014 semester.

Students were given a pre-test in the first two weeks of the fall course and a post-test on the final day of class in the spring semester. To account and control for social desirability bias, the surveys were administered by the researchers, not the course instructors. Participation in the survey was voluntary.

Measures and Variables. A paper version of the Leadership Attitudes and Beliefs Scale (LABS-III) (Wielkiewicz, 2002) along with questions related to participants' personal characteristics was used as the pre-test and post-test instrument in this study. The LABS-III is a 28-item instrument which examines leadership thinking among two constructs or scales: Hierarchical Thinking and Systemic Thinking. Each scale consisted of 14 items and were measured on a five-point summated scale: 1(Strongly Disagree), 2(Disagree), 3(Neither Disagree nor Agree), 4(Agree), and 5(Strongly Disagree). The hierarchical scale measures beliefs about leadership as being more positional, where leaders are responsible for successes and failures within an organization. The systemic scale measures beliefs about leadership being everyone's responsibility and an organization's chances for success are greater when there is open communication and adaptability (Wielkiewicz, 2000; Wielkiewicz, 2002). Both scales have established convergent and discriminative validity (Wielkiewicz, 2002). LABS-III has been used in other research studies to measure college students' understanding and assessment of leadership (Fischer, Overland, \& Adams, 2010; Ho \& Odom, 2015; Thompson, 2006; Wielkiewicz, 2000; Wielkiewicz, 2002). Eight additional demographic questions were added for data analysis purposes. Included in the demographic information was a question asking participants if they had previously experienced leadership and if so, to provide up to three of the most influential leadership experiences they have had to date.

\section{Data Analysis}

To address objective one and describe the leadership experiences of L3C students at the beginning of joining the $\mathrm{L} 3 \mathrm{C}$ and after their second semester in the $\mathrm{L} 3 \mathrm{C}$, researchers assigned the students' reported experiences into one of five categories: student organization, sports team, faith-based, work or business, and community service or arts. Because students enter the L3C their first semester of college, many of the reported influential leadership experiences are from their high school activities. Additionally, the pre-test was administered early in the fall semester prior to when students are able to join collegiate student organizations; and the post-test was administered near the close of the participants' second semester of college, so students could respond with high school experiences and/or experiences they gained during college.

Students could list up to three different, influential leadership experiences, and were asked to report the organization name, type, and their position within the organization. The total number of leadership experiences reported was $273(N=273)$. Fifty-six of the sixty students in the pre-test $(93.3 \%$ ) listed previous leadership experiences, while fifty of the fifty-five students in the post-test $(90.9 \%)$ listed previous leadership experiences. Furthermore, not all study participants provided three leadership experiences for the pre-test or the post-test; therefore, the leadership experience populations are 147 and 126 for the pre-test and post-test, respectively. 
For data analysis purposes, the organization type was coded as follows: student organization sponsored by academic institution, official sports teams, faith-based organizations, work or business, and community service or cultural arts. Since post-test leadership experience responses were not limited to the student's time in college, we included both all post-test responses and the collegiate-only responses (see Table 1). Twelve students, or $21.8 \%$ of the post-test participants, included membership in the L3C in their response. These twelve responses also account for $27.9 \%$ of the post-test: college only student organization responses; the only common response in the data set. Thus, the L3C is seen as a meaningful leadership experience for a sizable portion of those who participate in it.

Table 1

Descriptive Statistics for Previous Leadership Experiences by Category (N=273)

\begin{tabular}{lccc}
\hline & $\begin{array}{c}\text { Pre-Test } \\
(\mathrm{n}=147)^{\mathrm{a}}\end{array}$ & $\begin{array}{c}\text { Post-Test: all } \\
(\mathrm{n}=126)^{\mathrm{b}}\end{array}$ & $\begin{array}{c}\text { Post-Test: college } \\
\text { only }(\mathrm{n}=55)^{\mathrm{c}}\end{array}$ \\
\cline { 2 - 4 } Category & $\%(f)$ & $\%(f)$ & $\%(f)$ \\
\hline Student Organization & $60.5(89)$ & $75.0(87)$ & $78.2(43)^{\mathrm{d}}$ \\
\hline Sports Team & $10.2(15)$ & $8.7(11)$ & $1.8(1)$ \\
\hline Faith-based & $14.3(21)$ & $12.9(15)$ & $14.5(8)$ \\
\hline Work or Business & $2.7(4)$ & $4.3(5)$ & $1.8(1)$ \\
\hline Community Service or Arts & $12.2(18)$ & $7.0(8)$ & $3.6(2)$ \\
\hline
\end{tabular}

Note: ${ }^{a} 56$ of 60 students in the pre-test reported up to three previous, influential leadership experiences for a total of 147 experiences

b 50 of the 55 students in the post-test reported up to three previous, influential leadership experiences for a total of 126 experiences

c 38 of 55 students in the post-test reported collegiate leadership experiences on the posttest for a total of 55 experiences

${ }^{\mathrm{d}} 12$ of 55 students $(21.8 \%)$ in the post-test listed the L3C as one of the three most influential leadership experiences they have had today (27.9\% of responses are the L3C)

Table 2 details descriptive statistics for previous leadership experiences based on organization category, as previously defined, and positional vs. non-positional status. For the purposes of this study, positional leadership was defined as: president or vice-president, captain of a sports team, director of a program, or senior leader of a community service organization. All other responses were classified as non-positional leadership experiences. Twelve of the thirty-nine non-positional student organization responses $(30.8 \%)$ were membership in the L3C. 
Table 2

Descriptive Statistics for Previous Leadership Experiences by Category and Positional Leadership $(N=273)$

\begin{tabular}{|c|c|c|c|}
\hline & $\begin{array}{l}\text { Pre-Test } \\
(\mathrm{n}=147)^{\mathrm{a}}\end{array}$ & $\begin{array}{l}\text { Post-Test: all } \\
(\mathrm{n}=126)^{\mathrm{b}}\end{array}$ & $\begin{array}{l}\text { Post-Test: college } \\
\text { only }(\mathrm{n}=55)^{\mathrm{c}}\end{array}$ \\
\hline Category & $\%(f)$ & $\%(f)$ & $\%(f)$ \\
\hline \multicolumn{4}{|c|}{ Student Organization } \\
\hline Positional & $24.0(35)$ & $18.3(23)$ & $7.2(4)$ \\
\hline Non-positional & $37.0(54)$ & $50.8(64)$ & $70.9(39)^{\mathrm{d}}$ \\
\hline \multicolumn{4}{|l|}{ Sports Team } \\
\hline Positional & $9.6(14)$ & $7.1(9)$ & $1.8(1)$ \\
\hline Non-positional & $0.7(1)$ & $0.8(2)$ & $0.0(0)$ \\
\hline \multicolumn{4}{|l|}{ Faith-based } \\
\hline Positional & $1.4(2)$ & $0.0(0)$ & $0.0(0)$ \\
\hline Non-positional & $13.0(19)$ & $11.9(15)$ & $14.5(8)$ \\
\hline \multicolumn{4}{|l|}{ Work or Business } \\
\hline Positional & $0.0(0)$ & $0.0(0)$ & $0.0(0)$ \\
\hline Non-positional & $2.7(4)$ & $4.0(5)$ & $1.8(1)$ \\
\hline \multicolumn{4}{|c|}{ Community Service or Arts } \\
\hline Positional & $4.1(6)$ & $1.6(2)$ & $0.0(0)$ \\
\hline Non-positional & $8.2(12)$ & $4.8(6)$ & $3.6(2)$ \\
\hline \multicolumn{4}{|c|}{$\begin{array}{l}\text { Note: }{ }^{\text {a }} 56 \text { of } 60 \text { students in the pre-test reported up to three previous, influential leadership } \\
\text { experiences for a total of } 147 \text { experiences } \\
\text { b } 50 \text { of the } 55 \text { students in the post-test reported up to three previous, influential leadership } \\
\text { experiences for a total of } 126 \text { experiences } \\
\text { c } 38 \text { of } 55 \text { students in the post-test reported collegiate leadership experiences on the post- } \\
\text { test for a total of } 55 \text { experiences } \\
\text { d } 12 \text { of } 55 \text { students }(21.8 \%) \text { in the post-test listed the L } 3 \mathrm{C} \text { as one of the three most } \\
\text { influential leadership experiences they have had to date ( } 30.8 \% \text { of the non-positional } \\
\text { responses are the L3C) }\end{array}$} \\
\hline
\end{tabular}


Table 3

Descriptive Statistics for Previous Leadership Experiences by Category, Gender, and Positional Leadership $(N=273)$

\begin{tabular}{|c|c|c|c|c|c|c|}
\hline \multirow{3}{*}{ Category } & \multirow{2}{*}{\multicolumn{2}{|c|}{$\begin{array}{c}\begin{array}{c}\text { Pre-Test } \\
(\mathrm{n}=147)^{\mathrm{a}}\end{array} \\
\%(f)\end{array}$}} & \multirow{2}{*}{\multicolumn{2}{|c|}{$\begin{array}{c}\text { Post-Test: all } \\
(\mathrm{n}=126)^{\mathrm{b}}\end{array}$}} & \multicolumn{2}{|c|}{$\begin{array}{l}\text { Post-Test: college } \\
\text { only }(\mathrm{n}=55)^{\mathrm{c}}\end{array}$} \\
\hline & & & & & & $(f)$ \\
\hline & Male & Female & Male & Female & Male & Female \\
\hline \multicolumn{7}{|c|}{ Student Organization } \\
\hline Positional & $10.9(16)$ & $12.9(19)$ & $6.3(8)$ & $11.9(15)$ & $3.6(2)$ & $3.6(2)$ \\
\hline Non-positional & $8.8(13)$ & $27.9(41)$ & $9.5(12)$ & $42.1(52)$ & $16.4(9)$ & $54.5(30)$ \\
\hline \multicolumn{7}{|l|}{ Sports Team } \\
\hline Positional & $4.1(6)$ & $5.4(8)$ & $0.8(1)$ & $7.1(6)$ & $0.0(0)$ & $1.8(1)$ \\
\hline Non-positional & $0.0(0)$ & $0.7(1)$ & $1.6(2)$ & $1.6(2)$ & $0.0(0)$ & $0.0(0)$ \\
\hline \multicolumn{7}{|l|}{ Faith-based } \\
\hline Positional & $0.7(1)$ & $0.7(1)$ & $0.0(0)$ & $0.0(0)$ & $0.0(0)$ & $0.0(0)$ \\
\hline Non-positional & $2.7(4)$ & $10.2(15)$ & $1.6(2)$ & $10.3(13)$ & $0.0(0)$ & $14.5(8)$ \\
\hline \multicolumn{7}{|l|}{ Work or Business } \\
\hline Positional & $0.0(0)$ & $0.0(0)$ & $0.0(0)$ & $0.0(0)$ & $0.0(0)$ & $0.0(0)$ \\
\hline Non-positional & $0.7(1)$ & $2.0(3)$ & $0.8(1)$ & $3.2(4)$ & $0.0(0)$ & $1.8(1)$ \\
\hline \multicolumn{7}{|c|}{$\begin{array}{l}\text { Community Service } \\
\text { or Arts }\end{array}$} \\
\hline Positional & $1.4(2)$ & $2.7(4)$ & $0.8(1)$ & $0.8(1)$ & $0.0(0)$ & $0.0(0)$ \\
\hline Non-positional & $1.4(2)$ & $6.8(10)$ & $0.8(1)$ & $4.0(5)$ & $0.0(0)$ & $3.6(2)$ \\
\hline
\end{tabular}

Note: ${ }^{a} 56$ of 60 students in the pre-test reported up to three previous, influential leadership experiences for a total of 147 experiences

b 50 of the 55 students in the post-test reported up to three previous, influential leadership experiences for a total of 126 experiences

c 38 of 55 students in the post-test reported collegiate leadership experiences on the posttest for a total of 55 experiences

As previous research has noted, gender influences how an individual conceptualizes or defines leadership (Fischer, Overland, \& Adams, 2010; Haber, 2012; Wielkiewicz, Fischer, Overland, \& Sinner, 2012). Descriptive statistics of frequencies and percentages were run for the pre-test and post-test data to examine if changes in the study population composition could influence any results between the two data points. For the pre-test, 42 individuals self-identified as female $(70 \%)$ and 18 individuals self-identified as male (30\%). For the post-test, 39 individuals self-identified as female (70.9\%) and 16 individuals self-identified as male (29.1\%). Therefore, gender percentages remain fairly constant throughout the course of the study and any significant changes in leadership mindset were not influenced by changes in the population composition.

Descriptive statistics were run for the pre-test and post-test data by gender and category to examine if the distribution of responses could influence the results. For purposes of this 
analysis, faith-based, sports teams, and community service or arts were defined as valuing more systemic thinking, whereas work or business was defined as valuing more hierarchical thinking. Student organizations were defined as neutral. See Table 3.

To address Objective 2, descriptive statistics including frequencies, percentages, mean scores, and standard deviations from the pre-test and post-test instrument were reported to describe L3C students' leadership mindsets at the beginning and end of the programmatic year. According to Agresti and Finlay (2009), attitudes about distinctive factors of groups who differ can be revealed through descriptive statistics. Scores ranged on the pre-test from 31 to 66 for the Hierarchical thinking scale and from 48 to 67 for the Systemic thinking scale. On the post-test, scores ranged from 33 to 68 for the Hierarchical thinking scale and 42 to 70 for the Systemic thinking scale. For both the pre-test and post-test, the majority of participants scored below the midline threshold of 56 on the Hierarchical thinking scale and above the threshold on the Systemic thinking scale (Table 6).

To address Objective 3 and determine whether significant differences existed between the pre-test and post-test scores between hierarchical and systemic thinking, mean scores were examined across all students (Tables 4 and 5). Students were not assigned individual identifiers, thus the data is an aggregate view at the beginning and end of the program year, rather than documentation of individual development. Independent sample t-tests (Field, 2009) were conducted for each scale to determine if differences existed between students' pre-test and posttest scores for hierarchical and systemic thinking (Table 6).

The limitations of this study are the small size of the sample, the disproportionally low number of male students in the sample, and that the study only examined the leadership mindset of students within one collegiate leadership-themed LLC. Furthermore, the study is limited in that we did not control for the pre-collegiate leadership experiences of the students. Therefore, it is difficult to know the extent to which these previous leadership experiences continue to influence the students' leadership mindsets. However, the findings support previous research that formal leadership coursework does impact students' conceptualization of leadership (Ho \& Odom, 2015), collaborative learning is more supportive (Cross, 1998), and the residential aspect is an important extension of the classroom (Longerbeam et al, 2007), all of which can aide coordinators of other leadership-themed living-learning communities. 
Table 5

Descriptive Statistics for Systemic Thinking $(N=60$ (pre) and $N=55$ (post))

Responses \% $(f)$

\begin{tabular}{|c|c|c|c|c|c|c|c|c|}
\hline Item & & $\begin{array}{l}\text { Strongly } \\
\text { Agree }\end{array}$ & Agree & $\begin{array}{l}\text { Neither } \\
\text { Agree nor } \\
\text { Disagree }\end{array}$ & Disagree & $\begin{array}{l}\text { Strongly } \\
\text { Disagree }\end{array}$ & $M$ & $S D$ \\
\hline \multirow{2}{*}{$\begin{array}{l}\text { Individuals need to take initiative } \\
\text { to help their org. accomplish } \\
\text { its goals. }\end{array}$} & Pre & $29.5(36)$ & $13.9(17)$ & $0.8(1)$ & $1.6(2)$ & $3.3(4)$ & 4.32 & 1.13 \\
\hline & Post & $69.0(40)$ & 22.4 (13) & $3.4(2)$ & $0.0(0)$ & $0.0(0)$ & 4.69 & 0.54 \\
\hline \multirow{2}{*}{$\begin{array}{l}\text { An organization needs flexibility } \\
\text { in order to adapt to a rapidly } \\
\text { changing world }\end{array}$} & Pre & $23.8(29)$ & $22.1(27)$ & $3.3(4)$ & $0.0(0)$ & $0.0 .(0)$ & 4.42 & 0.62 \\
\hline & Post & $53.4(31)$ & 37.9 (22) & $3.4(2)$ & $0.0(0)$ & $0.0(0)$ & 4.53 & 0.57 \\
\hline \multirow{2}{*}{$\begin{array}{l}\text { Leadership should encourage } \\
\text { innovation. }\end{array}$} & Pre & $20.5(25)$ & $23.0(28)$ & $4.1(5)$ & $0.8(1)$ & $0.8(1)$ & 4.25 & 0.82 \\
\hline & Post & $58.6(34)$ & 32.8 (19) & $3.4(2)$ & $0.0(0)$ & $0.0(0)$ & (1. & 0.57 \\
\hline \multirow{2}{*}{$\begin{array}{l}\text { Organizations must be ready to } \\
\text { adapt to changes that occur } \\
\text { outside the org }\end{array}$} & Pre & $22.1(27)$ & $24.6(30)$ & $1.6(2)$ & $0.8(1)$ & $0.0(0)$ & 4.38 & 0.64 \\
\hline & Post & $56.9(33)$ & 32.8 (19) & $5.2(3)$ & $0.0(0)$ & $0.0(0)$ & 4.55 & 0.60 \\
\hline \multirow{2}{*}{$\begin{array}{l}\text { Everyone in an organization is } \\
\text { responsible for accomplishing } \\
\text { org goals. }\end{array}$} & Pre & $22.1(27)$ & $24.6(30)$ & $1.6(2)$ & $0.8(1)$ & $0.0(0)$ & 4.38 & 0.64 \\
\hline & Post & $43.1(25)$ & $48.3(28)$ & $3.4(2)$ & $0.0(0)$ & $0.0(0)$ & 4.42 & 0.57 \\
\hline \multirow{2}{*}{$\begin{array}{l}\text { Effective leadership seeks out } \\
\text { resources needed to adapt to a } \\
\text { changing world. }\end{array}$} & Pre & 24.6 & (28) & $0.8(1)$ & & $0.0(0)$ & 4.45 & 0.62 \\
\hline & Post & $56.9(33)$ & 29.3 (17) & $8.6(5)$ & $0.0(0)$ & $0.0(0)$ & 4.51 & 0.66 \\
\hline \multirow{2}{*}{$\begin{array}{l}\text { Leadership processes involve the } \\
\text { participation of all } \\
\text { organization members. }\end{array}$} & Pre & $22.1(27)$ & $18.0(22)$ & $4.9(6)$ & $3.3(4)$ & $0.0(0)$ & 4.22 & 0.89 \\
\hline & Post & $53.4(31)$ & 31.0 (18) & $6.9(4)$ & & & 4.42 & 0.79 \\
\hline \multirow{2}{*}{$\begin{array}{l}\text { An effective org develops its } \\
\text { human resources }\end{array}$} & Pre & 15) & (35) & $7.4(9)$ & & & 0 & 0.64 \\
\hline & Post & $31.0(18)$ & $60.3(35)$ & $3.4(2)$ & $0.0(0)$ & $0.0(0)$ & 4.29 & 0.53 \\
\hline \multirow{2}{*}{$\begin{array}{l}\text { Good leadership requires that } \\
\text { ethical issues have high } \\
\text { priority. }\end{array}$} & Pre & $13.9(17)$ & $23.8(29)$ & $9.0(11)$ & $1.6(2)$ & $0.8(1)$ & 3.98 & 0.87 \\
\hline & Post & $39.7(23)$ & $44.8(26)$ & $10.3(6)$ & $0.0(0)$ & $0.0(0)$ & 4.31 & 0.66 \\
\hline \multirow{2}{*}{$\begin{array}{l}\text { Organizational action should } \\
\text { improve life for future } \\
\text { generations. }\end{array}$} & $\mathrm{P}$ & 24) & $23.0(28)$ & $5.7(7)$ & & & 4.25 & 0.73 \\
\hline & Post & $60.3(35)$ & $27.6(17)$ & $6.9(4)$ & $0.0(0)$ & $0.0(0)$ & 4.56 & 0.63 \\
\hline \multirow{2}{*}{$\begin{array}{l}\text { Successful organizations make } \\
\text { continuous learning their } \\
\text { highest priority. }\end{array}$} & Pre & $14.8(18)$ & $30.3(37)$ & $3.3(4)$ & $0.0(0)$ & $0.0(0)$ & 4.24 & 0.57 \\
\hline & Post & $29.3(17)$ & $53.4(31)$ & $10.3(6)$ & $1.7(1)$ & $0.0(0)$ & 4.16 & 0.69 \\
\hline \multirow{2}{*}{$\begin{array}{l}\text { Leadership activities should } \\
\text { foster discussions about the } \\
\text { future. }\end{array}$} & Pre & $9.0(11)$ & $32.0(39)$ & $7.4(9)$ & $0.0(0)$ & $0.0(0)$ & 4.03 & 0.59 \\
\hline & Post & 32.8 (19) & $53.4(31)$ & $8.6(5)$ & $0.0(0)$ & $0.0(0)$ & 4.26 & 0.62 \\
\hline \multirow{2}{*}{$\begin{array}{l}\text { Anticipating the future is one of } \\
\text { the most important roles of } \\
\text { leadership processes. }\end{array}$} & Pre & $6.6(8)$ & $31.1(38)$ & $9.8(12)$ & $1.6(2)$ & $0.0(0)$ & 3.87 & 0.68 \\
\hline & Post & $24.1(14)$ & $50.0(29)$ & $15.5(9)$ & $5.2(3)$ & $0.0(0)$ & 3.98 & 0.80 \\
\hline \multirow{2}{*}{$\begin{array}{l}\text { Environmental preservation } \\
\text { should be a core value of } \\
\text { every org }\end{array}$} & Pre & & $11.5(14)$ & $18.0(22)$ & $11.5(14)$ & $4.9(6)$ & 2.93 & 1.07 \\
\hline & Post & $6.9(4)$ & $41.4(24)$ & $34.5(20)$ & $6.9(4)$ & $5.2(3)$ & 3.40 & 0.93 \\
\hline
\end{tabular}

Note: Grand Mean = 4.13 (pre) and 4.33 (post), Overall SD = 0.17 (pre) and 0.11 (post) 
Table 6

Independent t-tests with Thinking Scales and Survey Administration $(N=60$ (pre) and $N=55$

\begin{tabular}{l|l|c|c|c|c|c}
\multicolumn{7}{l}{$($ post)) } \\
\hline Thinking Scale & $\begin{array}{l}\text { Survey } \\
\text { Administration }\end{array}$ & $N$ & $M$ & $S D$ & $t$ & $p$ \\
\hline \multirow{2}{*}{ Hierarchical } & Pre-test & 60 & 43.1 & 7.31 & -1.06 & 0.292 \\
& Post-test & 55 & 44.5 & 6.93 & & \\
\hline \multirow{2}{*}{ Systemic } & Pre-test & 60 & 57.6 & 4.84 & $-3.31^{*}$ & 0.001 \\
\cline { 2 - 6 } & Post-test & 55 & 60.7 & 5.21 & & \\
\hline
\end{tabular}

Note: $* p<0.05$

\section{Conclusions and Implications}

This study sought to investigate leadership experiences and leadership mindsets of students participating in a leadership living learning community. The first objective was to describe the leadership experiences of L3C students prior to attending college and after their second semester in college. This study revealed that a majority of the students who enrolled in the L3C had previous leadership experience prior to college. Thus the study population shows signs of self-selection bias and supports past research that those who believe leadership is important and are interested in leadership will apply to and engage in collegiate leadershipthemed programming (Shertzer et al., 2005). Furthermore, the majority of the reported leadership experiences were in non-positional roles, indicating that the students came to college believing leadership was not only experienced in formal organizational positions, which could explain the initial high systemic mindset score. Conversely, a small percentage of students did not report any prior leadership experience, which could be indicative of a more hierarchical view of leadership: no formal title/position of leadership, no leadership experience.

Objective two of this study was to describe students' leadership mindsets in terms of hierarchical and systemic thinking. As students enter the L3C, they have higher systemic thinking scores than hierarchical thinking scores. Yet, the mean values for the systemic scale show a slight positive affinity towards systemic thinking while the mean values for the hierarchical scale were neutral. Even though the students in the study had a higher systemic thinking score, their propensity towards systemic thinking was similar to their propensity towards hierarchical thinking. But, the higher percentage of women in the study population and the categorization of their previous leadership experience in organizations that value systemic thinking could explain the higher mean values for systemic thinking, which supports Haber's (2012) findings.

The final objective for this study was to compare students' leadership mindsets from the beginning of the L3C to the end of the second semester of the L3C. When the students in the study exited the L3C, they had higher scores for both the hierarchical and systemic scales than when they entered. Moreover, the mean values for both the hierarchical and systemic scales were higher, meaning that there was an increase in agreement with the statements tied to each scale. These findings imply that the equivalent of one introductory academic leadership course is not sufficient to significantly alter students' hierarchical views towards leadership. But there was a significant difference between the pre-test and post-test scores for the systemic thinking 
scale, which is encouraging. Whether this change results from the academic portion of the L3C, student maturation, the communal or relational focus of a shared living environment, the students' experiences in non-positional leadership roles in their out-of-class activities or some combination of the above cannot be determined from this study alone.

\section{Recommendations}

This study provides a reference point to examine how participating in a leadershipthemed LLC influences first-year students' leadership mindsets at a single university. A followup qualitative study drawing from past and present students within the L3C may provide a deeper understanding of how their participation in the L3C influenced their leadership mindsets, and is suggested. Additionally, it is recommended that this study be replicated with a new cohort of L3C participants with each participant receiving a unique identifier so that individual development can be measured over the course of the programmatic year. The individual identifier could also enable the researchers to "check in" periodically and systematically with students regarding the longer-term influences participation in the $\mathrm{L} 3 \mathrm{C}$ has had on their leadership mindsets throughout their collegiate careers and beyond. Furthermore, it is recommended that this study be conducted with non-LLC first-year students for comparison and to examine if the L3C experience or the first year of college in general impacts students' leadership mindsets.

\section{References}

Agresti, A., \& Finlay, B. (2009). Statistical methods for the social sciences (4th ed.). Upper Saddle River, NJ: Prentice Hall.

Andenoro, A. C., Allen, S. J., Haber-Curran, P., Jenkins, D. M., Sowcik, M., Dugan, J. P., \& Osteen, L. (2013). National leadership education research agenda 2013-2018: Providing strategic direction for the field of leadership education. Retrieved from Association of Leadership Educators website: http://leadershipeducators.org/ResearchAgenda.

Cross, K. (1998). Why learning communities? Why now? About Campus, 3(3), 4-11.

Davis, T. M., \& Murrell P. H. (1993). A structural model of perceived academic, personal, and vocational gains related to college student responsibility. Research in HigherEducation, 34(3), 267-289.

Dunn, M. S., \& Dean, L. A. (2013). Together we can live and learn: Living-learning communities as integrated curricular experiences. SCHOLE: A Journal of Leisure Studies and Recreation Education, 28(1), un-paginated.

Field, A. (2009). Discovering statistics using SPSS (3rd ed.). Thousand Oaks, CA: Sage.

Fischer, D. V., Overland, M., \& Adams, L. (2010). Leadership attitudes and beliefs of incoming first-year college students. Journal of Leadership Education, 9(1), 1-16. 
Fischer, D. V., Wielkiewicz, R. M., Stelzner, S. P., Overland, M., \& Meuwissen, A. S. (2015). Changes in leadership attitudes and beliefs associated with the college experience: A longitudinal study. Journal of Leadership Education, 14(1), 14-32.

Haber, P. (2012). Perceptions of leadership: An examination of college students' understandings of the concept of leadership. Journal of Leadership Education, 11(2), 26-51.

Ho, S. P., \& Odom, S. F. (2015). Mindsets of leadership education undergraduates: An approach to program assessment. Journal of Leadership Education, 14 (1), 92-106, doi: 1012806(V14/11), R6

Inkelas, K. K., Johnson, D., Lee, Z., Daver, Z., Longerbeam, S. D., Vogt, K., \& Leonard, J. B. (2006). The role of living-learning programs in students' perceptions of intellectual growth at three large universities. NASPA Journal, 43(1), 115-143.

Inkelas, K. K. \& Weisman, J. L. (2003). Different by design: An examination of student outcomes among participants in three types of living-learning programs. Journal of College Student Development, 44(3), 335-368.

Inman, P., \& Pascarella, E. (1998). The impact of college residence on the development of critical thinking skills in college freshmen. Journal of College StudentDevelopment. 39(6), 557-568.

Keating, K., Roch, D., \& Burgoon, L. (2014). Development readiness for leadership: the Differential effects of leadership courses on creating "ready, willing, and able"learners. Journal of Leadership Education. 13(3), 1-16 doi:1012806/V13/I3/R1

Komives, S. R. Longerbeam, S. D., Mainella, F., Osteen, L., Owen, J. E., \& Wagner, W. (2009). Leadership identity development: Challenges in applying a developmental model. Journal of Leadership Education, 8(1), 11-47.

Komives, S. R., Longerbeam, S. D., Owen, J. E., Mainella, F. C., \& Osteen, L. (2006). A leadership identity development model: Applications from a grounded theory. Journal of College Student Development, 47(4), 401-418. doi: 10.1353/csd.2006.0048

Komives, S. R., Owen, J. E., Longerbeam, S. D. Mainella, F. C., \& Osteen, L. (2005). Developing a leadership identity: A grounded theory. Journal of College Student Development, 46(6), 593-611. doi:10.1353/csd.2005.0061

Longerbeam, S. D., Inkelas, K. K., \& Brower, A. M. (2007). Secondhand benefits: Student outcomes in residence halls with living-learning programs. Journal of College and University Student Housing, 34(2), 20-30.

Northouse, P. (2016). Leadership theory and practice (7th ed). Thousand Oaks, CA: Sage. 
Pike, G. R. (1999). The effects of residential learning communities and traditional residential living arrangements on educational gains during the first year of college. Journal of College Student Development. 40(3), 269-284.

Powell, A. (Ed). (1981). The experimental college. Cabin John, MD: Seven Locks Press, Inc.

Rocconi, L. M. (2011). The impact of learning communities on first year students' growth and development in college. Research in Higher Education, 52(2), 178-193.

Shertzer, J., Wall, V., Frandsen, A., Guo, Y., Whalen, D. F., \& Shelley II, M. C. (2005). Four dimensions of student leadership: What predicts students' attitudes toward leadership development? The College Student Affairs Journal, 25(1), 85-108.

Thompson, M. D. (2006). Student leadership process development: An assessment of contributing college resources. Journal of College Student Development, 47(3), 343-350.

Thompson, M. D. (2013). Student leadership development and orientation: Contributing resources within the liberal arts. American Journal of Education Research, 1(1), 1-6.

Wielkiewicz, R. M. (2000). The leadership attitudes and beliefs scale: An instrument for evaluating college students' thinking about leadership and organizations. Journal of College Student Development, 41(3), 335-346.

Wielkiewicz, R. M. (2002). Validity of the leadership attitudes and beliefs scale: Relationships with personality, communal orientation, and social desirability. Journal of College Student Development, 43(1), 108-118.

Wielkiewicz, R. M., Fischer, D. V., Overland, M., \& Sinner, A. M. (2012). Leadership attitudes and beliefs of incoming first year college students: A multi-institutional study of gender differences. Journal of Leadership Education, 11(2), 1-25.

Wielkiewicz, R. M., Prom, C. L., \& Loos, S. (2005). Relationships of the leadership attitudes and beliefs scale with student types, study habits, life-long learning, and GPA. College Student Journal, 39(1), 31-44.

\section{Author Biographies}

Allison L. Dunn is a graduate assistant and Ph.D. student within the Department of Agricultural Leadership, Education, \& Communications at Texas A\&M University. Her research interests include leadership education, the intersection of curricular and co-curricular leadership programs, student leader motivation, and the leadership activities of first-year and firstgeneration college students.

Summer F. Odom is an Assistant Professor in the Department of Agricultural Leadership, Education, \& Communications (ALEC) at Texas A\&M University. She teaches courses in 
personal and professional leadership. Dr. Odom received her Ph.D. in Human Resource Development in May 2011. Some of her research interests include programmatic assessment and evaluation of leadership programs and the psychological development of leaders, followers, and learners.

Lori L. Moore is an Associate Professor in the Department of Agricultural Leadership, Education, and Communications at Texas A\&M University. She teaches undergraduate and graduate leadership classes and is the co-coordinator for the university-wide Leadership Living Learning Community (L3C). Her primary research interests are in the area of collegiate leadership programming.

Craig Rotter, Ph.D serves as the Assistant Director for Academic Support Initiatives for the Department of Residence Life and Assistant Lecturer in the Department of Agricultural Leadership, Education \& Communications (ALEC) at Texas A\&M University. He teaches undergraduate leadership courses and co-coordinates the Texas A\&M Leadership Living Learning Community (L3C) Program with Dr. Lori Moore. His primary research focus is collegiate leadership with an emphasis on high impact learning programs (HIPS). 